\title{
Nitrogen release kinetics of organic nutrient sources in two benchmark soils of Indo-Gangetic plains
}

\author{
Manpreet S. Mavi*, B. S. Sekhon, Jagdeep Singh and O. P. Choudhary \\ Department of Soil Science, Punjab Agricultural University, Ludhiana-141 004 ( Punjab), INDIA \\ *Corresponding author. E-mail: mavims16@pau.edu \\ Received: April 7, 2016; Revised received: February 15, 2017; Accepted: May 15, 2017
}

\begin{abstract}
An understanding of the mineralization process of organic amendments in soil is required to synchronize $\mathrm{N}$ release with crop demand and protect the environment from excess $\mathrm{N}$ accumulation. Therefore, we conducted a laboratory incubation experiment to assess nitrogen mineralization potential of crop residues (rice and wheat straw) and organic manures (poultry manure, farmyard manure, cowpea and sesbania) in two benchmark soils (Typic Haplustept and Typic Ustifluvents) of semi-arid region of Punjab, India, varying in texture at field capacity moisture level at a constant temperature of $33 \pm 1^{\circ} \mathrm{C}$. Mineralization was faster during first 7 days of incubation in Typic Haplustept and upto 14 days in Typic Ustifluvents which subsequently declined over time. In both soils, net $\mathrm{N}$ mineralization continued to increase with increasing period of incubation (expect with crop residues) and was significantly higher in Typic Ustifluvents $\left(54-231 \mu \mathrm{g} \mathrm{g}^{-1}\right)$ than Typic Haplustept $\left(33-203 \mu \mathrm{g} \mathrm{g}^{-1}\right)$. Compared to unamended soils, percent $\mathrm{N}$ mineralized was highest is sesbania (35-40 \%) followed by cowpea (32-37 \%) and least in wheat (10-11\%) after 42 days of incubation. Thus, sesbania and cowpea may preferably be used to meet the large $\mathrm{N}$ demand during early period of plant growth. Further, mineralization rate constants $(\mathrm{k})$ also indicated that availability of mineral $\mathrm{N}$ was significantly higher with application of organic amendments than unamended control treatments in both soils. Therefore, it may be concluded that considerable economy in the use of inorganic $\mathrm{N}$ fertilizer can be employed if $\mathrm{N}$ mineralization potential of organic inputs is taken into consideration.
\end{abstract}

Keywords: Crop residues, Organic manures, Mineralization, Kinetics, Soil texture

\section{INTRODUCTION}

Rational use of organic inputs (such as animal manures, crop residues, green manures, sewage sludge and food industry wastes) and management of soil organic matter is very important for designing a sustainable agricultural system. There is now greater awareness that integrated plant nutrient management (IPNM) can provide, not only concrete benefits in terms of higher yields but simultaneously conserve and enhance the soil resource itself. However, it is important to understand the interplay between different sources of $\mathrm{N}$ to optimize the rate of application of organic manures and chemical fertilizers in an integrated nutrient management system to maintain adequate supply of nutrients for increased crop yields and reduced environmental pollution (Habai et al., 2016).

Nitrogen is one of the most important factors limiting crop production. In the modern agro-ecosystems, it was estimated that removal of as much as $300 \mathrm{~kg} \mathrm{~N}$ ha ${ }^{1} \mathrm{yr}^{-1}$ in the above ground portions of the harvested produce necessitates substantial inputs of nitrogen either through fertilizers, manures or $\mathrm{N}$-fixation via legumes to maintain soil productivity (Cassman et al., 2002). In India, $N$ consumption was increased from 0.06 Mt in 1951-52 to about $17 \mathrm{Mt}$ in $2014-15$ with a corresponding fourfold increase in food-grain production from 50.8 to $257.0 \mathrm{Mt}$ during this period (FAI, 2015). Thus, majority of the crop requirement for $\mathrm{N}$ in the country is supplied by applying very high doses of chemical fertilizers which are not environment friendly. Moreover, the nitrogen use efficiency in terms of plant uptake is generally low and varies greatly under different cropping and environmental conditions (Masclaux-Daubresse et al., 2010). Soil nitrogen (N) mineralization in agricultural soils is a process with important economic and environmental implications (Zebarth et al., 2009). Uncertainty in predicting soil $\mathrm{N}$ mineralization is a key limitation to making accurate fertilizer $\mathrm{N}$ recommendations for agricultural crops (Nett et al., 2012). Soil $\mathrm{N}$ mineralization, in combination with nitrification, is also an important controlling factor controlling the availability of soil nitrate for leaching and nitrous oxide emissions. This has led to increased interest in accurate prediction of soil $\mathrm{N}$ mineralization in agricultural soils. The rate of $\mathrm{N}$ mineralization in soil is controlled by a number of soil and environmental factors in a complex manner (Benbi and Richter, 2002). The important factors that dictate $\mathrm{N}$ mineralization kinetics include organic matter content, microbial biomass, soil texture, temperature and mois- 
ture (Fritschi et al., 2005; Wijanarko and Purwanto, 2016). Despite the complex controls on this process, and the involvement of a vast array of microbes from different taxonomic groups, the rate of mineralization is largely dependent on the quantity and quality (composition) of organic matter and the influence of environmental factors on biological activity (GómezMuñoz et al., 2015).

Further, the suitability of organic inputs as source of $\mathrm{N}$ also depends greatly on $\mathrm{N}$ mineralization in relation to crop demand. The $\mathrm{N}$ availability may control the kinetics of decomposition of crop residues, particularly those with high $\mathrm{C}$ : $\mathrm{N}$ ratio when the $\mathrm{N}$ requirements of the soil decomposers are not fulfilled by the residue or soil N content (Recous et al., 1995; Lupwayi et al., 2006). Thus, decomposition of residues and manures in soils vary with organic material and soils type and this needs to be investigated in an effort to synchronize $\mathrm{N}$ release with crop demand and protect the environment from excess $\mathrm{N}$ accumulation (Kpomblekou-A and Genus, 2012). Therefore, more information is required on the decomposition of crop residues and organic manures on N-transformations in different environments which can help fine tune the fertilizer $\mathrm{N}$ application to minimize leaching losses and prevent $\mathrm{N}$ pollution. Therefore, the present study was undertaken to find out the $\mathrm{N}$ mineralization potential of different organic inputs in two soils of varying texture in the Indo-Gangetic plains.

\section{MATERIALS AND METHODS}

Two bulk surface $(0-0.15 \mathrm{~m})$ soil samples representing
Typic Haplustept and Typic Ustifluvents from a semiarid region with varying properties were collected from farmer's field near Ludhiana $\left(30^{\circ} 50^{\prime} \mathrm{N}\right.$ and $75^{\circ}$ 41' E), Punjab, and the prevalent cropping system at both the soil sampling sites at village Hasanpur and Alliwal were rice-wheat. A portion of each sample was taken and passed through a sieve $(<2 \mathrm{~mm})$ for laboratory analysis. The samples were stored in a cool and dry place until the start of the study. The samples were analyzed for the soil properties like, $\mathrm{pH}$, electrical conductivity (EC) and organic carbon (OC) by procedure ascribed by Jackson (1967) and the values were given in Table 1. In order to study rate of $\mathrm{N}$ mineralization, crop residues viz. rice straw (RS) and wheat straw (WS) and organic manures viz. poultry manure (PM), farmyard manure (FYM), cowpea (CP) and sesbania (S) were selected. The C: N ratio of RS, WS, FYM, PM, CP, and $S$ were found to be 42:1, 48:1, 28:1, 25:1, 21:1 and 19:1, respectively.

Experimental design: Mineralization of $\mathrm{N}$ was studied in the laboratory by conducting aerobic incubation experiment under controlled conditions. Seventy five grams of air dried, ground and sieved $(<2 \mathrm{~mm})$ soil were taken in cylindrical wide mouthed plastic vials in triplicate. The finely ground crop residues and organic manures were mixed@2 per cent at dry weight basis with soil. Distilled water was added to each container so as to obtain field capacity moisture content and the vials were capped. The soil samples were incubated in a biological oxygen demand (BOD) incubator at $33 \pm 1^{\circ}$ $\mathrm{C}$ under field capacity water potential. Soil water content was maintained by weighing the containers on

Table 1. Properties of the experimental soils $(n=3)$.

\begin{tabular}{|c|c|c|}
\hline Soil characteristics & $\begin{array}{c}\text { Hasanpur silt loam } \\
\text { (Typic Haplustept) }\end{array}$ & $\begin{array}{c}\text { Alliwal clay loam } \\
\text { (Typic Ustifluvents) }\end{array}$ \\
\hline $\mathrm{pH}(1: 2$ soil : water suspension) & 8.0 & 8.2 \\
\hline EC dS m${ }^{-1}$ (1:2 soil: water solution) & 0.56 & 0.63 \\
\hline Sand $(\%)$ & 30.4 & 27.5 \\
\hline Silt $(\%)$ & 58.3 & 38.3 \\
\hline Clay $(\%)$ & 11.3 & 34.2 \\
\hline Texture & Silt loam & Clay loam \\
\hline Organic carbon $(\%)$ & 0.17 & 0.21 \\
\hline Alkaline $\mathrm{KMnO}_{4}-\mathrm{N}\left(\mathrm{mg} \mathrm{kg}^{-1}\right)$ & 53.1 & 62.9 \\
\hline $0.5 \mathrm{M} \mathrm{NaHCO}_{3}$ extractable $\mathrm{P}\left(\mathrm{mg} \mathrm{kg}^{-1}\right)$ & 4.8 & 5.7 \\
\hline $1 \mathrm{~N} \mathrm{NH}_{4} \mathrm{OAc}$ extractable $\mathrm{K}\left(\mathrm{mg} \mathrm{kg}^{-1}\right)$ & 150.4 & 200.8 \\
\hline$\left(\mathrm{NH}_{4}^{+}+\mathrm{NO}_{3}^{-}\right)-\mathrm{N}\left(\mathrm{mg} \mathrm{kg}^{-1}\right)$ & 28 & 42 \\
\hline
\end{tabular}

Table 2. Kinetic parameters of $\mathrm{N}$ mineralization in soils.

\begin{tabular}{lcccc}
\hline \multirow{2}{*}{ Treatment } & \multicolumn{2}{c}{ Typic Ustifluvents } & \multicolumn{2}{c}{ Typic Haplustepts } \\
\cline { 2 - 5 } Control & $\mathbf{N o}\left(\mathbf{m g ~ k g}^{-1}\right)$ & $\mathbf{k}\left(\mathbf{d a y}^{-1}\right)$ & \multicolumn{1}{c}{$\left.\mathbf{N o}_{\left.\mathbf{~} \mathbf{m g ~} \mathbf{~ k g}^{-1}\right)}\right)$} \\
Rice straw & $49.0 \pm 3.2$ & $0.0226 \pm 0.0094$ & $33.3 \pm 3.4$ & $0.0190 \pm 0.0053$ \\
Wheat straw & $79.7 \pm 5.6$ & $0.0342 \pm 0.0108$ & $55.0 \pm 11.5$ & $0.0272 \pm 0.0072$ \\
Farm yard manure & $71.8 \pm 4.9$ & $0.0280 \pm 0.0112$ & $45.0 \pm 6.4$ & $0.0225 \pm 0.0089$ \\
Poultry manure & $108.0 \pm 13.0$ & $0.0391 \pm 0.0128$ & $81.7 \pm 12.8$ & $0.0358 \pm 0.0132$ \\
Cowpea & $119.5 \pm 19.8$ & $0.0443 \pm 0.0154$ & $99.8 \pm 10.9$ & $0.0382 \pm 0.0105$ \\
Sesbania & $131.8 \pm 23.5$ & $0.0465 \pm 0.0103$ & $113.6 \pm 18.2$ & $0.0334 \pm 0.0158$ \\
\hline
\end{tabular}

LSD (0.05): soils= $3.62(\mathrm{No})$ and $0.0021(\mathrm{k})$; amendment=6.78 (No) and $0.0037(\mathrm{k})$; soil*amendment=9.59 (No) and $0.0052(\mathrm{k})$. The values following \pm are standard errors of estimates $(n=3)$. 

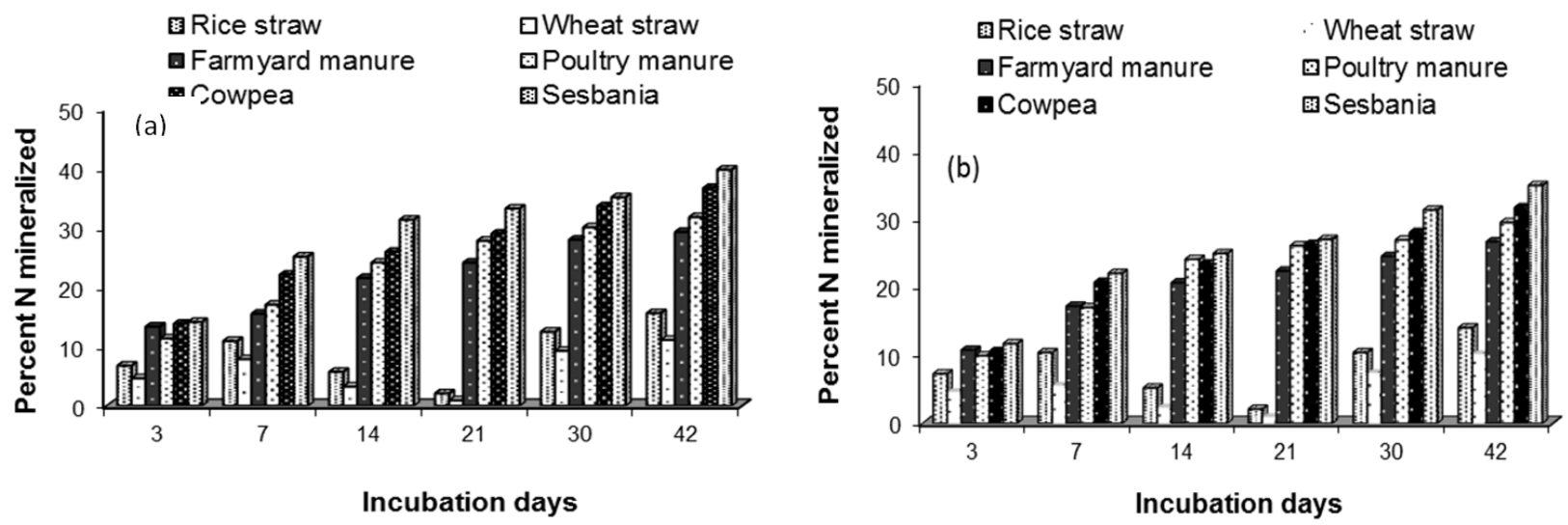

Fig. 1. Percent $N$ mineralized from different organic amendments during 42 days of incubation period in (a) Typic Ustifluvents and (b) Typic Haplustepts.

alternate days and replenishing the water lost. Independent sets for each incubation period were maintained to avoid soil disturbance during sampling. At the end of each incubation period, triplicate samples were drawn at $3,7,14,21,30$ and 42 days and whole soil in a vial was shaken with $2 \mathrm{M} \mathrm{KCl}$ for 1 hour. $\left(\mathrm{NH}_{4}{ }^{+}+\mathrm{NO}_{3}{ }^{-}\right)-\mathrm{N}$ in the extracts was determined following distillation method (Bremner and Keeney, 1966) using magnesium oxide $(\mathrm{MgO})$ and Devarda's alloy. Net $\mathrm{N}$ mineralization was estimated by subtracting the accumulated mineral $\mathrm{N}$ at day 42 from that at day zero and than subtracting this value for a given treatment from that for the control provided the apparent contribution of organic $\mathrm{N}$ to net mineralization.

First order kinetic model: The mathematical expression given by Stanford and Smith (1972) was used to assess No and $\mathrm{k}$ values. The approximates of No was obtained by using the expression: $\mathrm{Nt}=\mathrm{No}\left(1-\mathrm{e}^{-\mathrm{kt}}\right)$ where, ' $\mathrm{Nt}$ ' is cumulative amount of $\mathrm{N}$ mineralized $\left(\mathrm{mg} \mathrm{kg}^{-1}\right)$ during the specific periods of incubation, ' $t$ ' is the time of incubation in days, ' $\mathrm{k}$ ' is the rate constant $\left(\right.$ day $\left.^{-1}\right)$ and No is ' $N$ ' mineralization potential (mg $\mathrm{N} \mathrm{kg}^{-1}$ soil). The main assumption of the model is that at optimum temperature and moisture, organic $\mathrm{N}$ mineralization follows first order kinetics. Thus the single exponential model suggests that the potentially mineralizable $\mathrm{N}$ of a soil and its rate constant $(\mathrm{k})$ can be estimated by incubating the soil for specific time (t) at optimum conditions and measuring the $\mathrm{N}$ mineralized $(\mathrm{Nt})$.

Statistical analysis: Significance of differences $(\mathrm{P}<$ 0.05 ) between soils and amendments at different time intervals were tested using Genstat 14 (GenStat ${ }^{\circledR}$ for Windows10.0, VSN Int. Ltd, UK, 2005). Pearson correlation was used to examine the relationship between different amendments and $\mathrm{N}$ mineralization rates using SPSS.

\section{RESULTS AND DISCUSSION}

In general, $\mathrm{N}$ mineralization in soils (Typic Haplustept and Typic Ustifluvents) amended with crop residues
(RS, WS) and organic manures (PM, FYM, CP and S) increased with time. Irrespective of the soils, the time course of cumulative $\mathrm{N}$ mineralized under different amendments was faster during initial days of incubation (3-14 days) but subsequently the rates were slower. In both soils, 50-60 \% of total $\mathrm{N}$ mineralization had occurred by 7 days of incubation whereas the remaining occurred in the next 35 days. This suggested that initial rapid phase of mineralization was from an easily decomposable pool of organic matter whereas the latter phase was from a recalcitrant fraction. $\mathrm{Li}$ et al. (2011) also reported that mineralization passed through two phases initial 14 day rapid period followed by slower one.

The amount of $\left(\mathrm{NH}_{4}{ }^{+}+\mathrm{NO}_{3}{ }^{-}\right)-\mathrm{N}$ in untreated soil of Typic Ustifluvents was $21 \mathrm{mg} \mathrm{g}^{-1}$ and in Typic Haplustept was $18 \mathrm{mg} \mathrm{g}^{-1}$ after 3 days of incubation, which increased to 54 and $33 \mathrm{mg} \mathrm{g}^{-1}$ after 42 days of incubation in the respective soils. Similarly, No and k values in Table 2 also show significantly higher mineral $\mathrm{N}$ in soils of Typic Ustifluvents under different amendments as compared to Typic Haplustept. Thus, a comparison of mineral $\mathrm{N}$ recovered at various incubation times in the experimental soils indicate higher recovery in Typic Ustifluvents than Typic Haplustept which may be attributed to variation in clay content and organic carbon of these soils (Table 1). The soils of Typic Haplustept are coarser in texture and are not capable of holding $\mathrm{N}$ in clay lattice for greater period. Thus, Typic Ustifluvents soils behaved better in terms of recovery of mineral $\mathrm{N}$ at different incubation times with and without added amendments. Haer and Benbi (2003) also observed that organic carbon and clay content could account for 91 percent variability in $\mathrm{N}$ mineralization of soils. Similarly Gupta et al. (2003) and Sathya et al. (2009) reported that higher mineralization occurs in fine texture soils (more in clay loam than sandy laom) at different periods of incubation possibly due to the exposure of physically protected organic matter during grinding and fine sieving of the soils prior to incubation. In ad- 


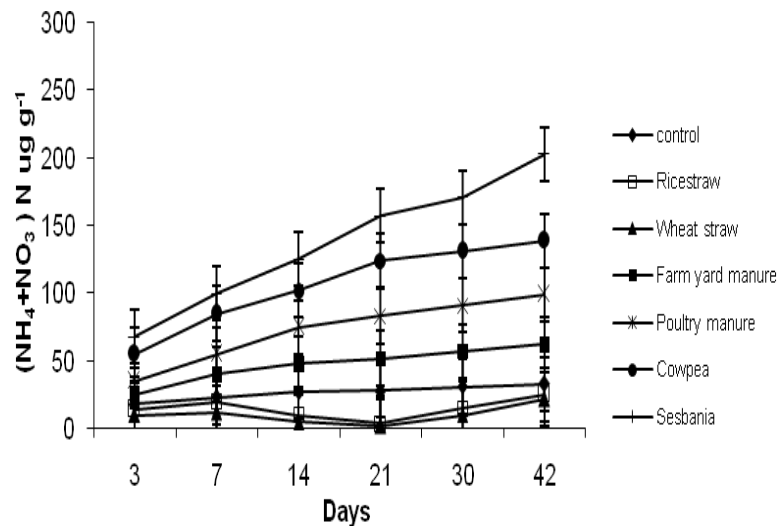

Fig. 2. Net $N$ mineralization in (a) Typic Ustifluvents and (b) Typic Haplustepts under different organic amendments at field capacity. The vertical bars indicate standard errors. $L S D$ (0.05): amendment $=2.18 ; \quad$ time $=1.99$; amend ment ${ }^{*}$ time $=5.37$.

dition, Hassink (1992) and Paul (2104) reported that in fine texture soils, a large part of organic matter present in the small pores cannot be reached by microorganisms and therefore, remain physically protected against decomposition. However, our results were in contrast to the findings of Thomsen et al. (2001) and Khalil et al. (2005) who reported that low content of clay can stimulate $\mathrm{N}$ mineralization in the soils due to sorption of the decomposition substrate onto mineral particles and incorporation into soil aggregates..

Further, our results indicate that there were considerable differences in the pattern of $\mathrm{N}$ mineralization from added organic amendments during the 42 days incubation period due to the difference in their chemical composition. Machinet et al. (2009) also found considerable variability and complexity in the pattern of $\mathrm{N}$ mineralization from plant residues. The added organic amendments regulated $\mathrm{N}$ mineralization process with sesbania $(\mathrm{S})>$ cowpea $(\mathrm{CP})>$ poultry manure $(\mathrm{PM})>$ farmyard manure $(\mathrm{FYM})>$ rice straw $(\mathrm{RS})>$ wheat straw (WS), irrespective of the texture of the soil. Several workers have reported substantial release of $\mathrm{N}$ from low $\mathrm{C}$ : $\mathrm{N}$ ratio organic amendments during incubation (Srinivas et al., 2006; Abera et al., 2012; Rahman et al., 2013). Application of green manures (S and $\mathrm{CP}$ ) increased $\mathrm{N}$ mineralization to a much greater extent than animal manures (PM and FYM) and crop residues (RS and WS) because they decompose rapidly on their incorporation into the soil (Nakhone and Tabatabai, 2008). Therefore, among all amendments, green manures were the best material for supplying quick and fast $\mathrm{N}$ to crops. Furthermore, it was observed that the use of RS and WS caused progressive reduction in percent $\mathrm{N}$ mineralized than the other organic inputs in both soils (Figs. 1 and 2). It clearly indicates that this initial phase of immobilization (7-21 days) with the application of crop residues may be due

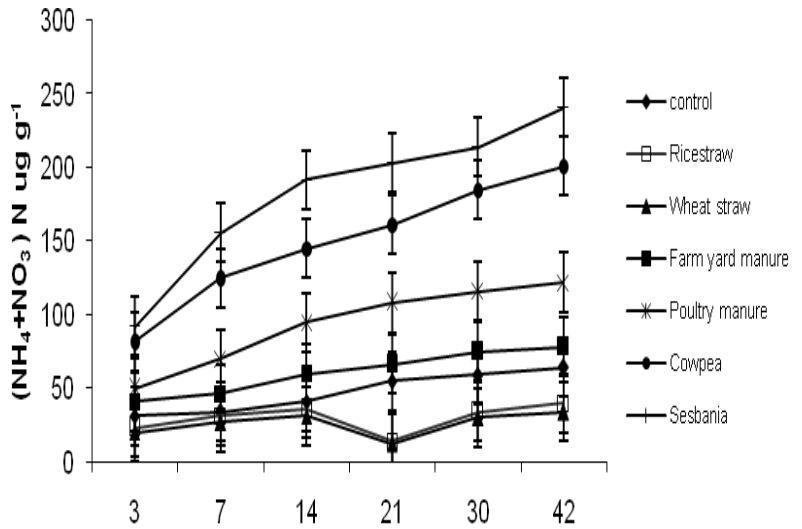

Fig. 3. Typic Ustifluvents.

to the microbial biomass utilizing $\mathrm{N}$ from inorganic pool, rather than directly from decomposing organic matter. Brar et al. (2004) also observed immobilization of $\mathrm{N}$ in wheat, maize and sunflower straw during the initial 2 to 3 weeks of incubation period. The longer period of immobilization of mineral $\mathrm{N}$ in wheat straw as compared with rice straw was due to slow decomposition on account of large $\mathrm{C}: \mathrm{N}$ ratio of the former than the later. Srinivas et al. (2006) suggested that microbiologically active soils in combination with $\mathrm{C}: \mathrm{N}$ ratio of the added organic material mainly regulate the $\mathrm{N}$ mineralization process in the amended soils.

Both organic amendments and time interval had significant effect on the net mineralization of $\mathrm{N}$ in both soils (Figs. 3 and 4). Application of sesbania and cowpea dominated the mineralization of $\mathrm{N}$ more so than for PM, FYM, RS, and WS. Accordingly, sesbania (203$231 \mathrm{mg} \mathrm{g}^{-1}$ soil) and cowpea (165-191mg g $\mathrm{g}^{-1}$ soil) amended soils depicted significantly higher net mineralization than other organic amendments. Similarly, data in Table 2 shows that regardless of the soil type, all the organic nutrient sources differed significantly with respect to their potentially mineralizable $\mathrm{N}_{\mathrm{o}}$ level (PMN). The potentially mineralizable $\mathrm{N}_{\mathrm{o}}$ level was largely governed by their $\mathrm{C}: \mathrm{N}$ ratio (Hadas et al., 2004; Jensen et al., 2005). The value of $\mathrm{k}$ for leguminous manures were quite similar to that reported by Kumar and Goh (2003) and Gale et al. (2004), although, some difference in values were observed that might derive from the slightly different methodologies in the respective studies or difference in the chemical properties of the different amendments.

When correlation were worked out between $\mathrm{N}$ mineralized and various chemical composition of all organic amendments at different periods during incubation, the organic $\mathrm{C}$ content was found to be significantly negatively correlated $\left(\mathrm{r}=-0.90^{*}\right.$ and $\mathrm{r}=-$ $0.89 *$ respectively) with $\mathrm{N}$ mineralization. However, there was a significantly strong positive $(\mathrm{r}=0.99 *$ in Typic Ustifluvents and $\mathrm{r}=0.97^{*}$ in Typic Haplustept) relationship of organic $\mathrm{N}$ concentration with the $\mathrm{N}$ mineralization in both soils $(p<0.05)$. Vityakon and 
Dangthaisong (2005) and Yanni et al. (2011) also found $\mathrm{N}$ content to be the most important parameter determining $\mathrm{N}$ mineralization. It was also found that rate constant $(\mathrm{k})$ correlated well to the chemical composition of the organic amendments (Johnson et al., 2007). The $\mathrm{k}$ values demonstrated a positive correlation with $\mathrm{N}$ content $\left(\mathrm{r}=0.88^{*}\right.$ in Typic Ustifluvents and $\mathrm{r}=0.67$ in Typic Haplustept, respectively) and $\mathrm{N}$ mineralization $(\mathrm{r}=0.90 *$ and $\mathrm{r}=0.75)$ whereas a significantly negative correlation $(\mathrm{r}=$ $-0.99 *$ and $\mathrm{r}=-0.90^{*}$ ) existed with $\mathrm{C}$ : $\mathrm{N}$ ratio of the amendments in both soils $(\mathrm{p}<0.05)$. Thus, this study emphasize the utility of $\mathrm{C}: \mathrm{N}$ ratio and $\mathrm{N}$ content of the organic amendments to predict the $\mathrm{k}$ values and $\mathrm{N}$ mineralization in both soils.

\section{Conclusion}

The results confirm that $\mathrm{N}$ concentration and $\mathrm{C}: \mathrm{N}$ ratio is a sound criterion for predicting $\mathrm{N}$ release from organic amendments. Irrespective of soils, maximum mineralization of $\mathrm{N}$ occurred with sesbania (203-236 $\left.\mathrm{mg} \mathrm{g}^{-1}\right)$ and minimum in crop residues $\left(10-30 \mathrm{mg} \mathrm{g}^{-1}\right)$. Thus, incorporation of sesbania should be encouraged to meet the large $\mathrm{N}$ demand during early period of plant growth especially in the $\mathrm{N}$ deficient soils of IndoGangetic plains. In addition, the study also indicates that use of organic resources in a reasoned way can ensure ecosystem sustainability against nutrient mining.

\section{REFERENCES}

Abera, G., Wolde-Meskel, E. and Bakken, L. R. (2012). Carbon and nitrogen mineralization dynamics in different soils of the tropics amended with legume residues and contrasting soil moisture contents. Biology and Fertility of Soils, 48: 51-66

Brar, B. S., Dhillon, N. S. and Mann, K. K. (2004). Effect of use of organic sources on kinetics of nitrogen mineralization. Journal of Plant Science Research, 20: 83-88

Benbi, D. K. and Richter, J. (2002). A critical review of some approaches to modelling nitrogen mineralization. Biology and Fertility of Soils, 35: 168-183

Bremner, J. M. and Keeney, D. R. (1966). Determination and isotope ratio analysis of different forms of nitrogen in the soils. 3 Exchangeable ammonium, nitrate and nitrite by extraction- distillation method. Soil Science Society of America Proceedings, 30: 577-582

Cassman, K. G., Dobermann, A. and Walters, D. T. (2002). Agroecosystems, nitrogen-use efficiency, and nitrogen management. AMBIO 31(2): 132-140

FAI (2015). Fertiliser Statistics, The Fertiliser Association of India (FAI), New Delhi, India.

Fritschi, F. B., Roberts, B. A., Rains, D. W., Travis, R. L. and Hutmacher, R. B. (2005). Recovery of residual ferlitizer-N and cotton residues-N by acala and pima cotton. Soil Science Society of America Journal, 69: 718 $-728$

Gale, E. S., Sullivan, D. M., Hemphill, D., Cogger, C. G., Bary, A. I. and Myhre, E. A. (2004). Predicting nitrogen availability from organic amendments: Laboratory, Field and Computer Simulation. www.puyallup. wsu.edu/soilmgmt/Abstract and pubs/IF-PostwerPreINAOrgAmend.pdf

Gómez-Muñoz, B., Hinojosa, M. B. and García-Ruiz, R. (2015). In situ net $\mathrm{N}$ mineralisation and nitrification under organic and conventionally managed olive oil orchards. Nutrient Cycling in Agroecosystems, 101: 223-239

Gupta, R. K., Arora, B. R. and Sharma K. N. (2003). Effect of urea and manures addition on mineral nitrogen content of the texturally divergent soils. Journal of Indian Society of Soil Science, 55(2): 203-205

Habai, M. R., Uzokwe, V. N., Mlay, P. D., Odeh, I., Singh, A., Buchan, D. and De Neve, S. (2016). Nitrogen mineralization dynamics of different valuable organic amendments commonly used in agriculture. $A p$ plied Soil Ecology, 101: 185-1 93

Hadas, A., Kautsky, L., Goek, M. and Kara, E. E. (2004). Rates of decomposition of plant residues and available nitrogen in soil, related to residue composition through simulation of carbon and nitrogen turnover. Soil Biology and Biochemistry, 36: 255-266

Haer, H. S. and Benbi, D. K. (2003). Modelling nitrogen mineralization kinetics in arable soils of semi-arid India. Arid Land Research and Management, 17: 153-168

Hassink, J. (1992). Effect of soil texture and structure on carbon and nitrogen mineralization in grassland soils. Biology and Fertility of Soils, 14: 126-134

Jackson, M. L. (1967). Soil Chemical Analysis. Prentice Hall of India Private Ltd, New Delhi.

Jensen, L. S., Salo, T., Palmason, F., Breland, T. A., Henriksen, T. M., Stenberg, B., Pedersen, A., Lundstrom, C. and Esala, M. (2005). Influence of biochemical quality on $\mathrm{C}$ and $\mathrm{N}$ mineralisation from a broad variety of plant materials in soil. Plant and Soil, 273: $307-326$

Johnson, M. F., Barbour, N. W. and Weyer, S. L. (2007). Chemical composition of crop biomass impacts its decomposition. Soil Science Society of America Journal, 71: $155-162$

Khalil, M. I., Hossain, M. B. and Schmidhalter, U. (2005). Carbon and nitrogen mineralization in different upland soils of the subtropics treated with organic materials. Soil Biology and Biochemistry, 37: 1507-1518

Kpomblekou-A, K. and Genus, A. (2012). Nitrogen transformations in broiler litter-amended soils. International Journal of Agronomy, 1-12

Kumar, K. and Goh, K. M. (2003). Crop residue and management practices: Effects on soil quality, soil nitrogen dynamics, crop yield and nitrogen recovery. Advances in Agronomy, 68: 197-280

Li, L. J., Zeng, D. H., Yu, Z. Y., Fan, Z. P., Yang, D. and Liu, Y. X. (2011). Impact of litter quality and soil nutrient availability on leaf decomposition rate in semi-arid grassland of Northeast China. Journal of Arid Environments, 75: 787-792

Lupwayi, N. Z., Clayton, G. W., O'Donovan, J. T., Harker, K. N., Turkington, T. K. and Soon, Y. K. (2006). Nitrogen release during decomposition of crop residues under conventional and zero tillage. Canadian Journal of Soil Science, 86: 11-19

Machinet, G. E., Bertrand, I., Chabbert, B., Matteau, F., Vil- 
lemin, G. and Recous, S. (20090. Soil biodegradation of corn root residues: interaction between chemical characteristics and the presence of colonizing microorganisms. Soil Biology and Biochemistry, 41:12531261

Masclaux-Daubresse, C., Daniel-Vedele, F., Dechorgnat, J., Chardon, F., Gaufichon, L. and Suzuki, A. (2010). Nitrogen uptake, assimilation and remobilization in plants: challenges for sustainable and productive agriculture. Annals of Botany, 10: 1141-1157

Nakhone, L. N. and Tabatabai, M. A. (2008). Nitrogen mineralization of leguminous crops in soils. Journal of Plant Nutrition and Soil Science, 171(2): 231-241

Nett, L., Ruppel, S., Ruehlmann, J., George, E. and Fink, M. (2011). Influence of soil amendment history on decomposition of recently applied organic amendments. Soil Science Society of America Journal, 76: $1290-1300$

Paul, E. A. (2014). Soil Microbiology, Ecology and Biochemistry. Academic Press, 598

Rahman, M. H., Islam, M. R., Jahiruddin, M., Puteh, A. B. and Mondal, M. M. A. (2013). Influence of organic matter on nitrogen mineralization pattern in soils under different moisture regimes. International Journal of Agriculture and Biology, 15: 55-61

Recous, S., Robin, D., Darwis, D. and Mary, B. (1995). Soil inorganic N availability: Effect on maize residue decomposition. Soil Biology and Biochemistry, 27: 15291538

Sathya, S., Pitchai, G. J. and Indirani, R. (2009). Effect of soil properties on availability of Nitrogen and Phosphorous in submerged and upland soil-A Review. Agricul- ture Review, 30 (1): 71-77

Srinivas, K., Singh, H. P., Vanaja, M., Raju, A. S. and Sharma, K. L. (2006). Effect of chemical composition of plant residues on nitrogen mineralization. Journal of Indian Society of Soil Science, 54 (3): 300-306

Stanford, G. and Smith, S. J. (1972). Nitrogen mineralization potential of soils. Soil Science Society of America Proceedings, 36: 465

Thomsen, I. K., Olesen, J. E., Schjonning, P., Jensen, B. and Christensen, B. T. (2001). Net mineralization of soil $\mathrm{MN}$ and ${ }^{15} \mathrm{~N}$-ryegrass residue in differently textured soils of similar mineralogical composition. Soil Biology and Biochemistry, 33: 277-285

Vityakon, P. and Dangthaisong, N. (2005). Environmental influences on nitrogen transformation of different quality tree litter under submerged and aerobic conditions. Agroforestry Systems, 63: 225-236

Wijanarko, A. and Purwanto, B. H. (2016). Comparison of two kinetics models for estimating $\mathrm{N}$ mineralization affected by different quality of organic matter in Typic Hapludults. Journal of Degraded and Mining Lands Management, 3: 577-583

Yanni, S. F., Whalen, J. K., Simpson, M. J. and Janzen, H. H. (2011). Plant lignin and nitrogen contents control carbon dioxide production and nitrogen mineralization in soils incubated with Bt and non-Bt corn residues. Soil Biology and Biochemistry, 43: 63-69

Zebarth, B. J., Scott, P. and Sharifi, M. (2009). Effects of straw and fertilizer nitrogen management for spring barley on soil nitrogen supply to a subsequent potato crop. American Journal of Potato Research, 86: 209. 217 